\title{
Fine-scale spatial and temporal genomic variation among Dungeness crab Cancer magister larval recruits in the California Current Ecosystem
}

\author{
Elizabeth M. J. Lee*, Kathleen G. O'Malley \\ State Fisheries Genomics Lab, Coastal Oregon Marine Experiment Station, Department of Fisheries and Wildlife, \\ Hatfield Marine Science Center, Oregon State University, Newport, Oregon 97365, USA
}

\begin{abstract}
Dynamic marine environments can shape complex spatial and temporal patterns in the population connectivity of marine species, and this is often exemplified in species with long larval phases. Here, we used a genotyping-by-sequencing (GBS) approach to examine fine-scale spatial and temporal genomic variation among Dungeness crab Cancer magister larval recruits sampled in the California Current Ecosystem. Specifically, we compared samples collected during expected- and late-season recruitment time periods within 2 consecutive years (2017 and 2018) at 2 sites in Oregon, USA (Yaquina Bay and Coos Bay). Evidence was found for high gene flow between the expected- and late-season recruits within each year and at both sites based on 1389 neutral loci. In contrast, strong genetic differentiation was observed between these 2 groups within each year and at both sites based on variation at 2 putatively adaptive loci. Contrary to prediction, the magnitude of genetic differentiation between these 2 seasonal groups was greater in 2017 when the Pacific Decadal Oscillation was stronger, upwelling was weaker, and the spring transition was later. Spatial genetic variation was not observed within 2017 or 2018. Comparing across years, expected- and late-season groups were differentiated at putatively adaptive loci. Interestingly, strong genetic differentiation was also observed between late-season groups across years. We found no evidence for cohesive larval dispersal among recruits based on genetic relatedness estimates. Overall, our findings provide evidence for high connectivity within Dungeness crab, but suggest that selective pressures and ocean conditions influence the genetic composition of larval recruits both intra- and inter-annually.
\end{abstract}

KEY WORDS: Genotyping-by-sequencing · Larval dispersal · Molecular ecology · Ocean conditions $\cdot$ Pelagic larval duration $\cdot$ Population connectivity $\cdot$ Population genomics

\section{INTRODUCTION}

Dynamic marine environments can produce complex spatial and temporal patterns of population connectivity in marine species (Hellberg et al. 2002, Selkoe et al. 2008). Population connectivity within a species can be defined by the movement of individuals among groups or locations (demographic connectivity) and by gene flow between groups of individuals (genetic connectivity) (Cowen et al. 2007, Hedgecock et al. 2007, Lowe \& Allendorf 2010, Kool

${ }^{*}$ Corresponding author: elizabethmjlee@gmail.com et al. 2013). For benthic marine species with pelagic larval phases, population connectivity is determined by both larval exchange throughout the species' range and by the ability of migrants to survive and reproduce at recruitment locations (Palumbi 2003, Hedgecock et al. 2007, Pineda et al. 2007, Cowen \& Sponaugle 2009).

Larval dispersal patterns of marine species are difficult to study in vast and variable ocean environments; however, genomic methods can be used to make inferences about these patterns (Pineda et al.

() The authors 2020. Open Access under Creative Commons by Attribution Licence. Use, distribution and reproduction are unrestricted. Authors and original publication must be credited. 
2007, Selkoe \& Toonen 2011, Marko \& Hart 2018). Dispersal and survival of migrants influence the scale and rate at which genetic drift and natural selection occur (Grosberg \& Cunningham 2001). Therefore, investigating the population genetic structure of a species provides an evolutionary supported framework for organism-environment interactions occurring within marine ecosystems and offers insight into larval dispersal patterns (Grosberg \& Cunningham 2001, Hellberg 2009). Moreover, the recent development of genotyping-by-sequencing (GBS) methods has enabled a shift in how population genetic structure is studied in marine species: from using only presumably neutral loci to also incorporating putatively adaptive loci and testing for divergent selection (Angeloni et al. 2012, Narum et al. 2013, Li \& Wang 2017). In some species, evidence for weak population genetic structure was found based on neutral loci while variation at putatively adaptive loci indicated divergent selection among populations (Nielsen et al. 2009, Gagnaire et al. 2015).

The Dungeness crab Cancer (Metacarcinus) magister is a valuable fishery species distributed throughout 3 large marine ecosystems along the west coast of North America: the California Current Ecosystem (CCE), the Salish Sea Ecosystem (SSE), and the Gulf of Alaska Ecosystem (GOA) (Wild \& Tasto 1983, Rasmuson 2013). The North Pacific Current, which stems from the North Pacific Gyre, bifurcates into the northern-flowing Alaska Current and the southernflowing California Current at the junction of these 3 ecosystems (Checkley \& Barth 2009). Reduced genetic connectivity between these ecosystems has been observed in marine species with long pelagic larval durations (PLDs) (e.g. shore crab Hemigrapsus nudus, hermit crab Pagurus hirsutiusculus; Kelly \& Palumbi 2010). In previous population genetic studies of adult benthic stage Dungeness crab from the CCE, SSE, and GOA, genetic differentiation was observed within and between ecosystems based on variation at neutral loci (microsatellites) (Jackson \& O'Malley 2017, O'Malley et al. 2017, Jackson et al. 2017).

Larval dispersal promotes genetic connectivity within Dungeness crab, since movement of the benthic invertebrate is restricted (Diamond \& Hankin 1985, Hildenbrand et al. 2011, Rasmuson 2013). The PLD of the Dungeness crab is documented as 3-4 mo long (Wild \& Tasto 1983). After hatching, the Dungeness crab develops through 5 pelagic zoeal stages into a final pelagic megalopa stage, which recruits to the nearshore benthic environment (Wild \& Tasto 1983). During the PLD, dispersal is influenced by ocean conditions (including physical oceanography) and behavior of the megalopae (Rasmuson \& Shanks 2014). The influence of ocean conditions on recruitment success has been studied by monitoring megalopae recruitment timing and abundance in Coos Bay, Oregon, USA, (CCE) for over 2 decades (Shanks \& Roegner 2007, Shanks et al. 2010, Rasmuson 2013, Shanks 2013, Rasmuson \& Shanks 2020). Based on this long-term timeseries, the researchers observed that years characterized by stronger negative Pacific Decadal Oscillation (PDO) indices, stronger upwelling, and earlier physical spring transitions were correlated with higher levels of megalopae recruitment (Shanks \& Roegner 2007, Shanks et al. 2010, Shanks 2013). These ocean conditions impact northern and southern alongshore transport and transport across the continental shelf.

Dungeness crab larval hatch timing varies with latitude and occurs later in the year within the northern range of the species, resulting in recruitment timing differences between ecosystems (i.e. CCE, SSE, GOA) (reviewed by Rasmuson 2013). The previously mentioned long-term studies on megalopae recruitment in Coos Bay have consistently documented recruitment later into the year than expected for the CCE (Shanks \& Roegner 2007, Shanks et al. 2010, Shanks 2013). Since the timing of this late-season recruitment matches that of northern ecosystems (GOA and SSE), researchers hypothesize that the April through July ('expectedseason') megalopae recruits originate from within the CCE, but the August through September ('lateseason') megalopae recruits originate from the GOA or SSE (Shanks 2013). This hypothesis is supported by the finding that higher abundances of late-season recruits were observed during years with a stronger negative PDO index, which has been correlated with a stronger southward transport in the CCE (Keister et al. 2011, Shanks 2013). Since genetic differentiation has been observed between adult Dungeness crabs from different ecosystems (CCE, SSE, and GOA) (Jackson \& O'Malley 2017, O'Malley et al. 2017, Jackson et al. 2017), genetic approaches can be used to test the hypothesis that late-season recruits in Coos Bay originate from a northern ecosystem; specifically, by quantifying the magnitude of genetic differentiation between expected-season and late-season recruits.

In a prior study, we used a GBS approach to examine genetic variation at both neutral and adaptive loci within the 2014 Dungeness crab megalopae recruits in Coos Bay. We found evidence for weak but significant genetic differentiation between expected- 
season recruits (May) and late-season recruits (September) based on variation at 1913 neutral loci and strong genetic differentiation based on variation at 2 putatively adaptive loci (Lee \& O'Malley 2020). The inference of the findings was limited due to only 1 year of data from a single location. However, the established methods and intriguing findings warranted further examination of fine-scale spatial and temporal patterns of genetic differentiation among Dungeness crab recruits using both neutral and adaptive loci.

Here, we again used a GBS approach, and tested for genetic differentiation among Dungeness crab megalopae recruits in 2 consecutive years and at 2 sites in the CCE. Our first objective was to test for intra-annual genetic differentiation between recruiting Dungeness crab megalopae in Coos Bay and Yaquina Bay, Oregon. We hypothesized that expectedseason recruits would be genetically differentiated from late-season recruits at both neutral and putatively adaptive loci if they originated from different ecosystems with divergent selective pressures. Our second objective was to test if the magnitude of intraannual genetic differentiation among the recruiting megalopae at the 2 sites varied across years, 2017 and 2018. We hypothesized that intra-annual genetic differentiation would be greater in 2018 when the positive PDO was weaker (Table 1), indicating the southern-flowing California Current was stronger, resulting in higher abundances of late-season recruits. Our third objective was to test for relatedness among individual Dungeness crab megalopae within the 2 CCE sites. We hypothesized that collections of recruiting Dungeness crab megalopae would exhibit higher relatedness than expected by chance and would contain full-siblings or half-siblings if cohesive larval dispersal occurred during the 3-4 mo larval phase.

\section{MATERIALS AND METHODS}

\subsection{Sample collection}

In 2017 and 2018, Dungeness crab megalopae recruits were collected from 2 sites within the CCE: Coos Bay $\left(43.34^{\circ} \mathrm{N}, 124.33^{\circ} \mathrm{W}\right)$ and Yaquina Bay $\left(44.62^{\circ} \mathrm{N}, 124.05^{\circ} \mathrm{W}\right)$, Oregon, USA (Fig. 1). At each site, a light trap was fished daily from 1 April through 31 October in 2017 and from 1 March through 31 October in 2018, following the methodology of Shanks et al. (2010). The daily abundance of megalopae caught in each trap was recorded.
For each site and year, 47 Dungeness crab megalopae were randomly selected for sequencing from the first day when more than 50 megalopae were collected and from the last day when more than 50 megalopae were collected (i.e. 8 collection timepoints; Fig. 2, Table 2). Collection timepoints were categorized as expected-season (April-July) or late-season (August-September), based on CCE life history timing documented in the literature (Rasmuson 2013, Shanks 2013). Megalopae from these 8 collection timepoints were preserved in $95 \%$ ethanol for genetic analyses.

\subsection{DNA sequencing, loci identification, and single nucleotide polymorphism (SNP) calling}

Individual megalopae were homogenized using a TissueLyser II (Qiagen), and genomic DNA was extracted from each megalopa using a DNeasy Blood and Tissue Kit (Qiagen). A modified version of the Elshire et al. (2011) GBS method was used to construct 4 libraries, each composed of 96 uniquely barcoded individual megalopae (Lee \& O'Malley 2020). The DNA of each megalopa was cut into fragments through a double digestion with 2 high-fidelity restriction enzymes, Sbfl and MspI. A unique barcode was then ligated to the DNA fragments of each sample, which allows for the identification of each sample when pooled. The DNA samples were pooled into groups (libraries) of 94 samples with 2 sample replicates, and the multiplexed DNA was amplified with Illumina sequencing primers using polymerase chain reaction (PCR). No size selection was performed on the libraries in order to capture a larger number of sequences for downstream analyses. The libraries were purified using a QIAquick PCR Purification Kit (Qiagen). Prior to sequencing, an Agilent 2100 Bioanalyzer (Agilent Technologies) was used to assess the library fragment sizes and infer the quality of the libraries. After quality assessment, each GBS library

Table 1. Ocean conditions in the California Current Ecosystem in 2017 and 2018: Pacific Decadal Oscillation (sum of monthly index January-July; JISAO 2019), upwelling (sum of daily upwelling index March-September; units: $\mathrm{Mt} \mathrm{s}^{-1}$ per $100 \mathrm{~m}$ of coastline; PFEL 2019), and physical spring transition (day of the year; Bograd et al. 2009)

\begin{tabular}{|lccc|}
\hline Ocean condition & $\begin{array}{c}\text { Mean } \\
(1998-2016)\end{array}$ & 2017 & 2018 \\
\hline Pacific Decadal Oscillation & 1.38 & 5.18 & 1.31 \\
Upwelling & 3827 & 3205 & 4377 \\
Spring transition & 104 & 115 & 104 \\
\hline
\end{tabular}




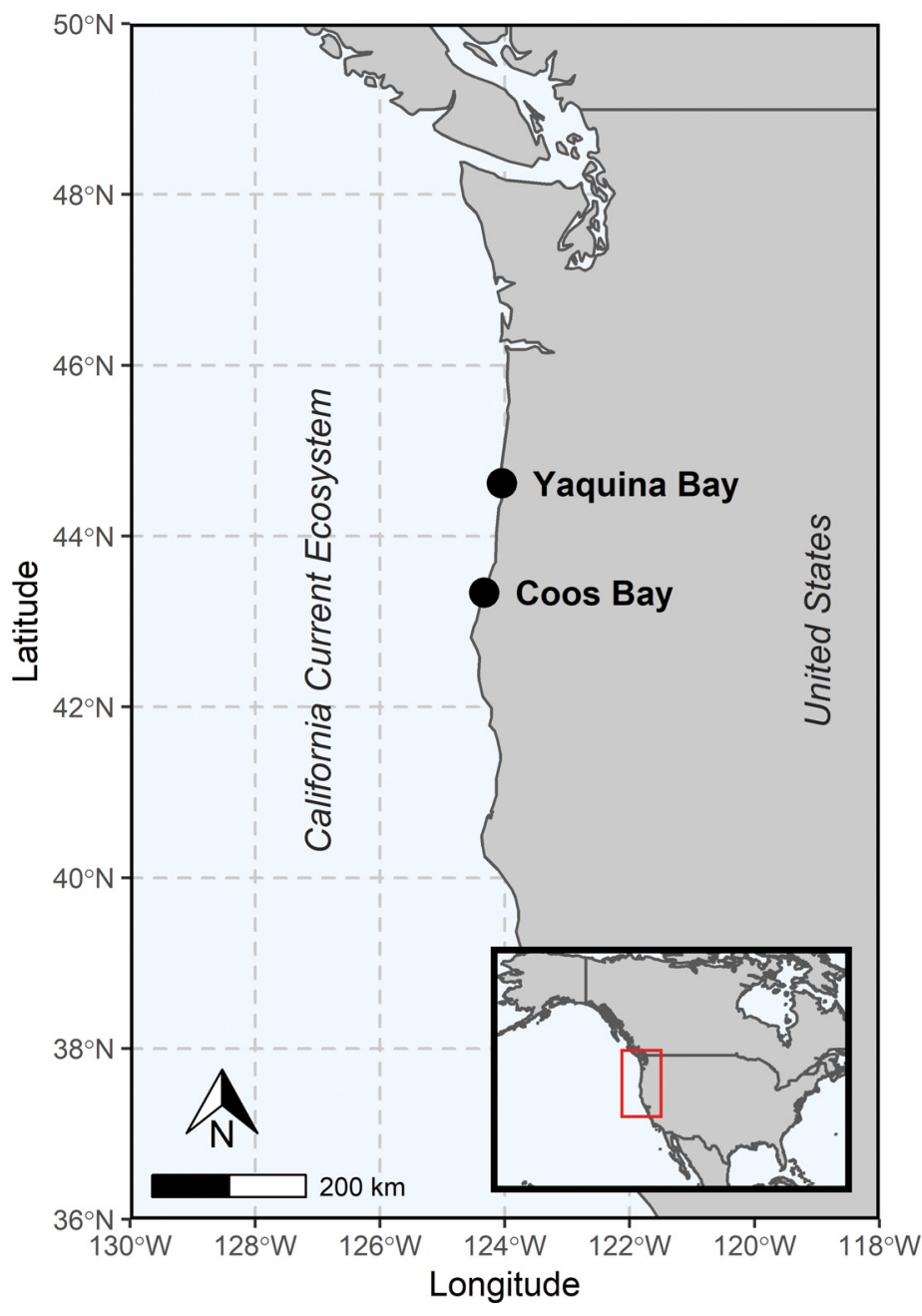

Fig. 1. Location of study sites in the California Current Ecosystem: Yaquina Bay and Coos Bay, Oregon, USA

was sequenced on a single lane of an Illumina HiSeq 3000 using 150 bp paired-end sequencing chemistry. Following the bioinformatic methods (documented in Text S1 in the Supplement at www.int-res.com/ articles/suppl/m649p067_supp.pdf), the raw sequence reads were assessed and filtered for quality and then the 'stacks' v. 2.2 program (Catchen et al. 2011, 2013, Rochette \& Catchen 2017) was used to identify a set of polymorphic loci within the samples and call SNPs between individuals.

\subsection{Calculating summary statistics}

Population genetic summary statistics were calculated among megalopae within each collection timepoint based on SNP genotypes of each sample. Expected heterozygosity $\left(H_{\mathrm{e}}\right)$, observed heterozygos- ity $\left(H_{0}\right)$, inbreeding coefficient $\left(F_{\mathrm{IS}}\right)$, and allelic richness $\left(A_{R}\right)$ were calculated using the program $\mathrm{R}$ v. 3.5.0 (R Core Team 2019) with the $\mathrm{R}$ package 'hierfstat' v. 0.4.22 (Goudet 2005). To test if $F_{\text {IS }}$ was significantly different from 0 (excess or deficit of heterozygotes) within each collection timepoint, a $95 \%$ confidence interval was calculated with 10000 bootstraps across all loci. The R package 'whoa' v. 0.0.1 (Anderson 2018) was used to examine the loci and estimate heterozygote miscall rate. The $\mathrm{R}$ package 'pegas' v. 0.10 (Paradis 2010) was used to determine if any loci within each collection timepoint departed from Hardy-Weinberg proportions (HWPs) with an exact test (Wigginton et al. 2005), and p-values were adjusted for multiple testing by applying a false discovery rate $(\mathrm{FDR})$ correction (q-value $<0.05$ ). The R package 'adegenet' v. 2.1.1 (Jombart et al. 2010) was used to conduct a discriminate analysis of principal components (DAPC) of all loci.

\subsection{Identifying putatively adaptive loci}

We tested for putatively adaptive differences between the expected-season and late-season megalopae recruits. Three outlier detection programs were used to identify loci with high $F_{\mathrm{ST}}$ (fixation index) estimates. The statistical approaches and error rates differ among the 3 programs (Narum \& Hess 2011). The program 'bayescan' v. 2.1 (Foll \& Gaggiotti 2008) was used with a prior of 100 and an FDR threshold of 0.05 (q-value). The program 'outflank' v. 0.2 (Whitlock \& Lotterhos 2015) was used with an FDR threshold of 0.01 (q-value). The program 'fsthet' v. 1.0.1 (Flanagan \& Jones 2017) was used with a $95 \%$ confidence interval. To conservatively identify outlier loci and reduce false positives, only loci identified by all 3 outlier detection programs were categorized as putatively adaptive loci for downstream analyses. The allele frequencies of the putatively adaptive loci were determined for each collection timepoint using the program 'vcftools' v. 0.1.13 (Danecek et al. 2011). The consensus sequences of the putatively adaptive loci were compared to the National Center for Biotechnology Information (NCBI) database using BLASTN and the 'somewhat similar sequences' parameter (Altschul et al. 1990).

\subsection{Genetic differentiation analyses}

The R package 'stampp' v. 1.5 .1 (Pembleton et al. 2013) was used to calculate pairwise $F_{\mathrm{ST}}$ estimates 


\section{7}
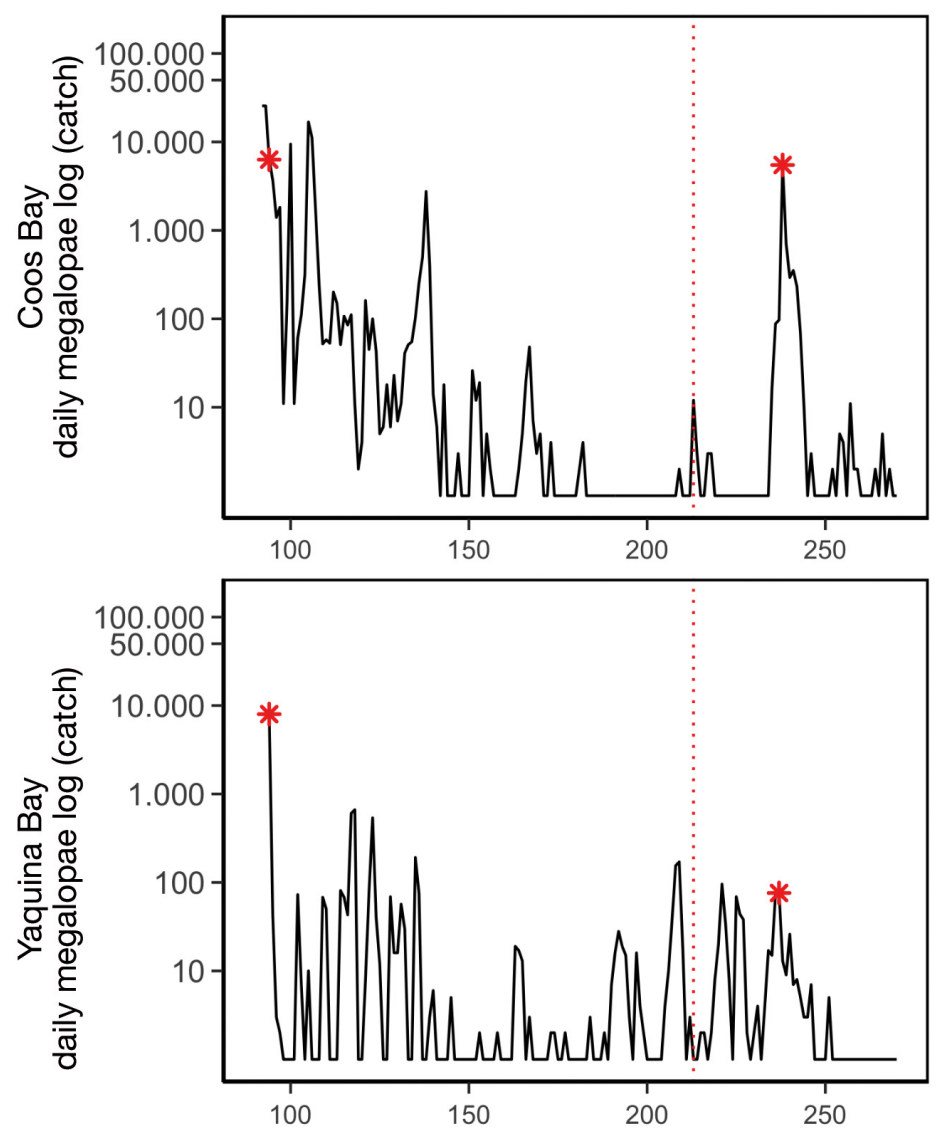

2018
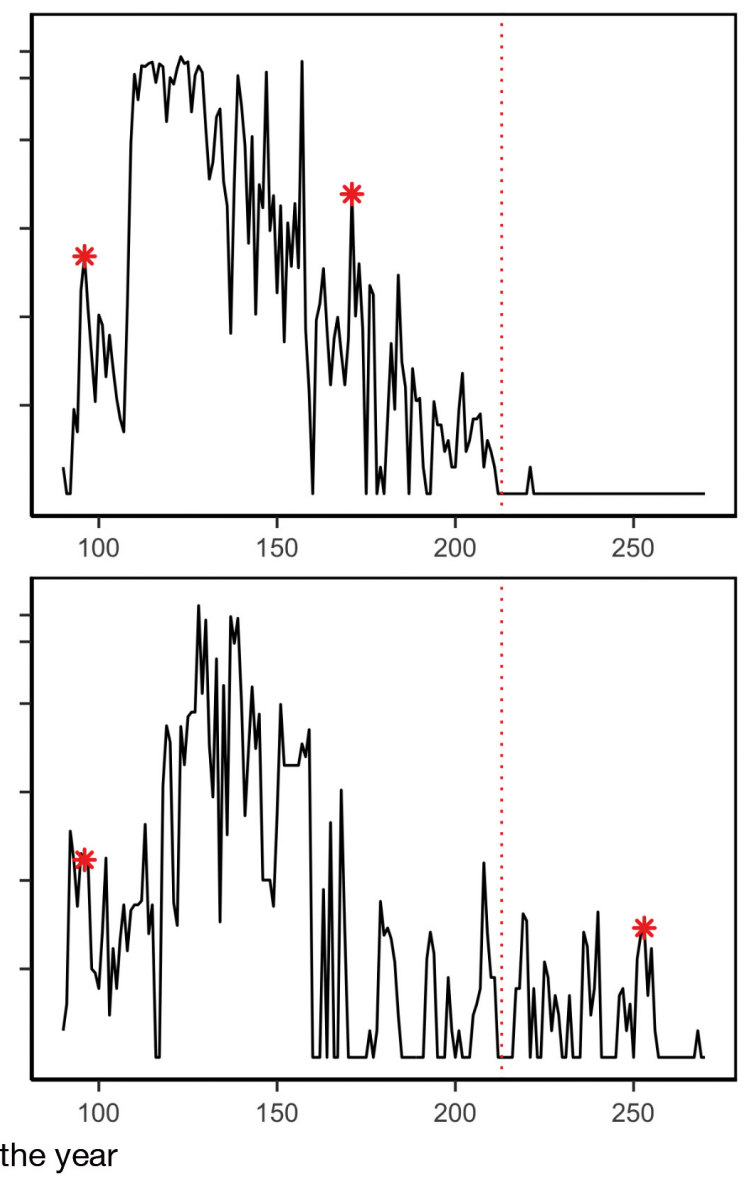

Fig. 2. Daily catch (log) of Dungeness crab megalopae from light traps fished in Coos Bay and Yaquina Bay, Oregon, in 2017 and 2018. Red dotted line indicates the divide between expected-season and late-season recruits (day of the year 213: 1 August). The red asterisks indicate the collection timepoints for genomic analysis within each year and site

(Weir \& Cockerham 1984) between each collection timepoint, site, and year using presumably neutral loci, putatively adaptive loci, and combined neutral and adaptive loci. Significance of the pairwise $F_{\mathrm{ST}}$ estimates based on neutral loci were quantified using 10000 bootstraps across all loci to determine 95\% confidence intervals and associated p-values. The $\mathrm{p}$ values were adjusted for multiple testing with an FDR correction ( $q$-value $<0.05$ ).

\subsection{Estimating the effective number of breeders}

The effective number of breeders $\left(\mathrm{N}_{\mathrm{b}}\right)$ of each collection timepoint and each year was estimated using 'NeEstimator' v. 2.1 (Do et al. 2014) with the singlesample linkage disequilibrium method (Waples \& Do 2010). Only neutral loci were used in the analyses. A p-critical value of 0.02 was used for analysis of each collection timepoint and a p-critical value of 0.01 was used for analysis of each year.

\subsection{Relatedness analyses}

To test for evidence of cohesive larval dispersal among the Dungeness crab megalopae recruits, relatedness (r) among individuals within each collection timepoint was measured. Only neutral loci were used in the relatedness analyses. All 7 relatedness estima-

Table 2. Number of Dungeness crab megalopae sampled at 2 sites in Oregon, USA, at each collection timepoint

\begin{tabular}{|llcccc|}
\hline Year & Site & Month & Day & $\begin{array}{c}\text { Recruitment } \\
\text { season }\end{array}$ & $\mathrm{n}$ \\
\hline 2017 & Coos Bay & April & 4 & Expected & 47 \\
& & August & 26 & Late & 47 \\
& Yaquina Bay & April & 4 & Expected & 48 \\
2018 & \multirow{2}{*}{ Coos Bay } & August & 26 & Late & 48 \\
& & Junil & 6 & Expected & 47 \\
& Yaquina Bay & April & 6 & Expected & 44 \\
& & August & 27 & Expected & 45 \\
& & & & Late & 45 \\
\hline
\end{tabular}


tors included in the 'coancestry' v. 1.0.1.9 (Wang 2011) program were implemented with 1000 pairs of simulated dyads and 6 defined relationship types (including half siblings and full siblings) using 100 simulated datasets. For each method, a Pearson's correlation coefficient was calculated between the simulated data and the observed kinship to determine the accuracy of each method (Table S1). The dyadic likelihood estimator of Milligan (2003) was chosen as the best estimator to test for relatedness among Dungeness crab megalopae recruits because it had the highest Pearson's correlation coefficient. Based on the 'coancestry' (Wang 2011) simulations with defined kinship pairs, it was determined that an r-value $>0.25$ between dyads was the appropriate threshold for identifying true half-siblings and full-siblings with $0 \pm 0$ (mean $\pm \mathrm{SD}$ ) false positives and $1.2 \pm 2.7$ false negatives per 100 datasets simulated. Using the empirical data, relatedness values were estimated for every megalopae dyad within each collection timepoint. Any dyads with rvalues indicating half or full siblings $(r>0.25)$ were reported. Additionally, the overall relatedness value of each collection timepoint was calculated, and significant differences between the relatedness estimates were determined using 1000 permutations and $95 \%$ confidence intervals.

\section{RESULTS}

\subsection{Intra-annual variation in megalopae recruit- ment within Coos and Yaquina Bays}

Megalopae recruitment varied between the 2 seasons (expected and late) and between the 2 sites (Coos Bay and Yaquina Bay) (Fig. 2, Table 3). In 2017, over 10 times more total megalopae were trapped in Coos Bay than Yaquina Bay, and more late-season megalopae were trapped in Coos Bay than Yaquina Bay. In 2018, over twice as many megalopae were trapped in Coos Bay than Yaquina Bay (Fig. 2, Table 3); however, only 1 late-season megalopa recruit was trapped in Coos Bay and 306 were trapped in Yaquina Bay.

The timing of megalopae recruitment varied between the 2 sites (Fig. 2, Table 3). In 2017, recruitment in Coos Bay continued for $17 \mathrm{~d}$ longer than in Yaquina Bay. However, the highest daily recruitment abundance in 2017 occurred in early April at both sites, and recruits were observed from April through September. In 2018, recruitment in Yaquina Bay lasted $35 \mathrm{~d}$ longer than in Coos Bay. At both sites, the first megalopae recruits of the year were observed on $30 \mathrm{March}$, and similarly, the highest daily abundance of the year was recorded on 8 May at both sites. However, the last recruits were caught on 9 August in Coos Bay, whereas recruits were caught in Yaquina Bay through 13 September.

\subsection{Inter-annual variation in megalopae recruit- ment within Coos and Yaquina Bays}

Ocean conditions (i.e. PDO, upwelling, and spring transition) differed between 2017 and 2018 (Table 1). Although both years were characterized by a positive PDO (defined by the sum of the monthly PDO index from January through July), the positive PDO was stronger in 2017, suggesting weaker southward transport. Annual upwelling (defined by the sum of the daily upwelling index from March through September) was lower in 2017 than 2018. Lastly, the physical spring transition occurred $11 \mathrm{~d}$ later in 2017 than 2018. The expectation based on previous research of these ocean conditions and recruitment abundances (Shanks \& Roegner 2007, Shanks et al. 2010, Shanks 2013) was that the total number of recruits and the number of late-season recruits would be higher in 2018 than 2017.

At both sites, an order of magnitude fewer megalopae were trapped in 2017 than in 2018 (Table 3). Moreover, inter-annual comparisons of megalopae abundances within each site showed differences in recruitment patterns. In Coos Bay, fewer total megalopae were trapped in 2017 than in 2018; however, more late-season megalopae were trapped in 2017

Table 3. Historic mean Dungeness crab megalopae abundances recorded in 19982001 and 2007-2016 in Coos Bay (Shanks 2013, A. Shanks upubl. data) and megalopae abundances in Coos Bay and Yaquina Bay in 2017 and 2018

\begin{tabular}{|ccccccc|}
\hline Year & Site & $\begin{array}{c}\text { Total } \\
\text { megalopae }\end{array}$ & $\begin{array}{c}\text { Expected- } \\
\text { season } \\
\text { megalopae }\end{array}$ & $\begin{array}{c}\text { Expected- } \\
\text { season } \\
\text { \% of total }\end{array}$ & $\begin{array}{c}\text { Late- } \\
\text { season } \\
\text { megalopae }\end{array}$ & $\begin{array}{c}\text { Late- } \\
\text { season of total }\end{array}$ \\
\hline $\begin{array}{c}\text { Historic } \\
\text { mean }\end{array}$ & Coos Bay & 719182 & 677493 & 94.20 & 41689 & 5.80 \\
2017 & Coos Bay & 117359 & 109983 & 93.72 & 7376 & 6.28 \\
& $\begin{array}{c}\text { Yaquina Bay } \\
2018\end{array}$ & 11960 & 11385 & 95.19 & 575 & 4.81 \\
& $\begin{array}{c}\text { Coos Bay } \\
\text { Yaquina Bay }\end{array}$ & 1501314 & 1501313 & 100.00 & 1 & 0.00 \\
\hline
\end{tabular}


than in 2018, only 1 late-season megalopa was trapped in 2018. The Coos Bay recruitment season was 47 d shorter in 2017 than in 2018. In Yaquina Bay, fewer megalopae were trapped in 2017 than in 2018 , but in 2017, slightly more late-season megalopae were trapped than in 2018 (Table 3). The length of the Yaquina Bay recruitment season was 17 d shorter in 2017 than in 2018.

\subsection{Genetic sampling}

The 2017 megalopae used for sequencing were collected on the same day at both sites: 4 April (expectedseason) and 26 August (late-season) (Table 2). Since the lengths of the recruitment seasons differed between the 2 sampling sites in 2018, only the expectedseason collection timepoints were from the same day at both sites: 6 April. The late-season collection timepoint from Yaquina Bay was 27 August. Late-season megalopae were not available from Coos Bay in 2018; instead, a second expected-season collection timepoint in Coos Bay was 20 June.

\subsection{Calculating summary statistics}

After filtering the sequence reads of the 4 GBS libraries (Text S2 and Fig. S1), 371 megalopae and 1391 loci remained for analysis (Table S2). Minimal differences were observed in genetic diversity measures among the 8 collection timepoints (Table 4). The range of allelic richness was 1.491-1.501. Furthermore, $H_{\mathrm{e}}$ (range: $0.2682-0.2745$ ) was greater than $H_{\mathrm{o}}$ (range: $0.2377-0.2490$ ), and all collection timepoints were significant for heterozygote deficiency with a $95 \%$ confidence interval $\left(F_{\text {IS }}\right.$ range: $0.0837-0.1047$ ). With the exception of the Yaquina Bay samples from 2017, the expectedseason collection timepoints hadlower inbreeding coefficients $\left(F_{\text {IS }}\right)$ than the late-season collection timepoints. A range of 54-90 loci within each collection timepoint were found to deviate from HWP (Table S3). However, these loci were not removed from the dataset because substructure may be present within collection timepoints; adult reproduction occurs among groups of individuals within limited geographic areas, and the groups of larvae mix offshore prior to recruitment and sampling. Filtering the sequences and loci reduced the chance that deviations from HWP were a result of genotyping errors or null alleles. The DAPC indicated that 2 groups could be differentiated among 1391 loci using more than 10 principal components (Fig. S2).

\subsection{Identifying putatively adaptive loci}

To identify putatively adaptive loci between expected- and late-season recruits, all April collection timepoints $(n=4)$ were grouped together to represent expected-season recruits, and all August collection timepoints $(\mathrm{n}=3)$ were grouped together to represent late-season recruits. The June 2018 expected-season collection timepoint in Coos Bay was excluded from the dataset when testing for outliers. Two putatively adaptive loci (CLocus_24 and CLocus_3063) were identified by all 3 outlier detection programs (Tables S4 \& S5). These 2 loci ( $>200 \mathrm{bp}$ ) did not align with the 2 putatively adaptive loci (>200 bp) identified by Lee \& O'Malley (2020). The remaining 1389 loci were categorized as presumably neutral.

The 2 putatively adaptive loci had varying allele frequencies at each collection timepoint (Table 5). In 2017 , the allele frequencies at the 2 putatively adaptive loci differed between the expected- and lateseason collection timepoints at both sites. In 2018, the allele frequencies at CLocus_3063 were different between expected- and late-season collection timepoints, and the allele frequencies at CLocus_24 were more similar between expected- and late-season collection timepoints. One of the 2 putatively adaptive

Table 4. Genetic summary statistics for 2017 and 2018 expected-season and lateseason Dungeness crab megalopae from Coos Bay and Yaquina Bay, Oregon, based on variation at 1391 loci. Number of individuals genotyped (n), expected heterozygosity $\left(H_{\mathrm{e}}\right)$, observed heterozygosity $\left(H_{\mathrm{o}}\right)$, inbreeding coefficient $\left(F_{\mathrm{IS}}\right)$, and allelic richness $\left(A_{R}\right)$ are listed for the expected-season and late-season megalopae at each site for each year

\begin{tabular}{|c|c|c|c|c|c|c|c|c|}
\hline Year & Site & Month & $\begin{array}{l}\text { Recruitment } \\
\text { season }\end{array}$ & $\mathrm{n}$ & $H_{\mathrm{e}}$ & $H_{\mathrm{o}}$ & $F_{\mathrm{IS}}$ & $A_{\mathrm{R}}$ \\
\hline \multirow[t]{4}{*}{2017} & \multirow[t]{2}{*}{ Coos Bay } & April & Expected & 47 & 0.2697 & 0.2451 & 0.0877 & 1.494 \\
\hline & & August & Late & 47 & 0.2689 & 0.2377 & 0.1047 & 1.492 \\
\hline & \multirow[t]{2}{*}{ Yaquina Bay } & April & Expected & 48 & 0.2712 & 0.2415 & 0.1022 & 1.496 \\
\hline & & August & Late & 48 & 0.2682 & 0.2400 & 0.0962 & 1.491 \\
\hline \multirow[t]{4}{*}{2018} & \multirow[t]{2}{*}{ Coos Bay } & April & Expected & 47 & 0.2724 & 0.2474 & 0.0909 & 1.498 \\
\hline & & June & Expected & 44 & 0.2731 & 0.2461 & 0.0950 & 1.499 \\
\hline & \multirow[t]{2}{*}{ Yaquina Bay } & April & Expected & 45 & 0.2732 & 0.2490 & 0.0837 & 1.499 \\
\hline & & August & Late & 45 & 0.2745 & 0.2481 & 0.0946 & 1.501 \\
\hline
\end{tabular}


Table 5. Allele frequencies at the 2 putatively adaptive loci (CLocus_24 and CLocus_3063) identified within the 2017 and 2018 expected-season and late-season Dungeness crab megalopae from Coos Bay and Yaquina Bay

\begin{tabular}{|c|c|c|c|c|c|c|c|c|}
\hline \multirow[t]{2}{*}{ Year } & \multirow[t]{2}{*}{ Site } & \multirow[t]{2}{*}{ Month } & \multirow{2}{*}{$\begin{array}{l}\text { Recruitment } \\
\text { season }\end{array}$} & \multirow[t]{2}{*}{$\mathrm{n}$} & \multicolumn{2}{|c|}{ CLocus_24 } & \multicolumn{2}{|c|}{ CLocus_3063 } \\
\hline & & & & & A Frequency & T Frequency & C Frequency & T Frequency \\
\hline \multirow[t]{4}{*}{2017} & \multirow[t]{2}{*}{ Coos Bay } & April & Expected & 47 & 0.9545 & 0.0455 & 0.6316 & 0.3684 \\
\hline & & August & Late & 47 & 0.4545 & 0.5455 & 0.2702 & 0.7297 \\
\hline & \multirow[t]{2}{*}{ Yaquina Bay } & April & Expected & 48 & 0.9268 & 0.0732 & 0.7368 & 0.2632 \\
\hline & & August & Late & 48 & 0.3780 & 0.6220 & 0.2632 & 0.7368 \\
\hline \multirow[t]{4}{*}{2018} & \multirow[t]{2}{*}{ Coos Bay } & April & Expected & 47 & 0.9047 & 0.0953 & 0.8461 & 0.1539 \\
\hline & & June & Expected & 44 & 0.9000 & 0.1000 & 0.7142 & 0.2858 \\
\hline & \multirow[t]{2}{*}{ Yaquina Bay } & April & Expected & 45 & 0.8536 & 0.1464 & 0.7875 & 0.2125 \\
\hline & & August & Late & 45 & 0.9744 & 0.0256 & 0.4054 & 0.5946 \\
\hline
\end{tabular}

loci (CLocus_24) aligned to a sequence in the NCBI database with a low Expect value (E-value: $2 \times 10^{-8}$ ), indicating a significant match to a predicted transcription factor, SOX-1-like in Pacific white shrimp Litopenaeus vannamei (NCBI Sequence ID: XM_ 027382823.1).

\subsection{Genetic differentiation}

Across sites, seasons, and years, the $F_{\mathrm{ST}}$ estimates based on variation at neutral loci were low $\left(F_{\mathrm{ST}}\right.$ range: 0.0000-0.0012) and nonsignificant after applying an FDR correction (q-value $<0.05$; Table 6 ). Similarly, $F_{\text {ST }}$ estimates were nonsignificant when including both presumably neutral and the 2 putatively adaptive loci (Table S6). $F_{\mathrm{ST}}$ estimates based on variation at the 2 putatively adaptive loci (Table 7) were notably higher compared to those based on the neutral loci.

In 2017, $F_{\mathrm{ST}}$ estimates between expected- and lateseason recruits based on the putatively adaptive loci ranged from $0.3411-0.4209$. The genetic differentia- tion was slightly lower in Coos Bay $\left(F_{\mathrm{ST}}=0.3411\right)$ compared to Yaquina Bay $\left(F_{\mathrm{ST}}=0.4209\right)$. However, low genetic differentiation $\left(F_{\mathrm{ST}}=0.0000\right.$ and 0.0048$)$ was observed when comparing seasonal groups between the 2 sites (e.g. expected-season from Yaquina Bay vs. expected-season from Coos Bay).

In 2018, the $F_{\mathrm{ST}}$ estimate between expected- and late-season recruits in Yaquina Bay based on the putatively adaptive loci was 0.2071 (Table 7). Due to low recruitment, there was no late-season collection timepoint in Coos Bay. When comparing the 2 expected-season collection timepoints (April and June) from Coos Bay, the $F_{\mathrm{ST}}$ estimate was 0 . However, a comparison of the 2 Coos Bay expected-season collection timepoints (April and June) to the Yaquina Bay late-season collection timepoint resulted in $F_{\mathrm{ST}}$ estimates $>0$ (April $F_{\mathrm{ST}}=0.1124$ and June $\left.F_{\mathrm{ST}}=0.1333\right)$ but lower than the intra-annual $F_{\mathrm{ST}}$ estimates within Yaquina Bay. Similar to 2017, there was no genetic differentiation when comparing seasonal groups between the 2 sites. Comparison of the 2018 expected-season recruits between Coos

Table 6. Pairwise $F_{\mathrm{ST}}$ estimates based on variation at the 1389 neutral loci identified within Dungeness crab megalopae collected in 2017 and 2018. No comparisons were significant after false discovery rate (FDR) correction. Late-season collection timepoints (i.e. August) are shaded in gray. Pairwise $F_{\mathrm{ST}}$ comparisons between expected- and late-season samples are in bold. Intra-annual $F_{\mathrm{ST}}$ estimates are shaded blue while inter-annual $F_{\mathrm{ST}}$ estimates are not shaded

\begin{tabular}{|c|c|c|c|c|c|c|c|c|c|}
\hline & & & 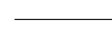 & - & 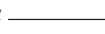 & - & $\longrightarrow$ & - & 8 \\
\hline & & & $-\mathrm{Coo}$ & s Bay- & -Yaqu & na Bay- & $-\mathrm{Coo}$ & Bay— & -Yaquina Bay- \\
\hline & & & April & August & April & August & April & June & April August \\
\hline 2017 & Coos Bay & April & & & & & & & \\
\hline & & August & 0.0011 & & & & & & \\
\hline & Yaquina Bay & April & 0.0004 & 0.0006 & & & & & \\
\hline & & August & 0.0009 & 0.0005 & 0.0004 & & & & \\
\hline 2018 & Coos Bay & April & 0.0000 & 0.0009 & 0.0007 & 0.0005 & & & \\
\hline & & June & 0.0008 & 0.0009 & 0.0000 & 0.0003 & 0.0000 & & \\
\hline & Yaquina Bay & April & 0.0000 & 0.0012 & 0.0004 & 0.0008 & 0.0000 & 0.0007 & \\
\hline & & August & 0.0000 & 0.0007 & 0.0007 & 0.0000 & 0.0008 & 0.0000 & 0.0000 \\
\hline
\end{tabular}


Table 7. Pairwise $F_{\mathrm{ST}}$ estimates based on variation at the 2 putatively adaptive loci identified within Dungeness crab megalopae collected in 2017 and 2018. Late-season collection timepoints (i.e. August) are shaded in gray. Pairwise $F_{\mathrm{ST}}$ comparisons between expected- and late-season samples are in bold. Intra-annual $F_{\mathrm{ST}}$ estimates are shaded blue while inter-annual $F_{\mathrm{ST}}$ estimates are not shaded

\begin{tabular}{|c|c|c|c|c|c|c|c|c|c|}
\hline & & & & -2 & 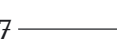 & - & $\longrightarrow$ & {[} & $18 \longrightarrow$ \\
\hline & & & $-\mathrm{CoO}$ & Bay- & -Yaqu & na Bay- & $-\mathrm{Coc}$ & Bay- & -Yaquina Bay- \\
\hline & & & April & August & April & August & April & June & April August \\
\hline 2017 & Coos Bay & April & & & & & & & \\
\hline & & August & 0.3411 & & & & & & \\
\hline & Yaquina Bay & April & 0.0048 & 0.3777 & & & & & \\
\hline & & August & 0.3896 & 0.0000 & 0.4209 & & & & \\
\hline 2018 & Coos Bay & April & 0.0000 & 0.3273 & 0.0000 & 0.3736 & & & \\
\hline & & June & 0.0000 & 0.3381 & 0.0000 & 0.3833 & 0.0000 & & \\
\hline & Yaquina Bay & April & 0.0399 & 0.3569 & 0.0000 & 0.3978 & 0.0024 & 0.0000 & \\
\hline & & August & 0.0687 & 0.2776 & 0.1590 & 0.3352 & 0.1124 & 0.1333 & 0.2071 \\
\hline
\end{tabular}

Bay and Yaquina Bay resulted in low $F_{\mathrm{ST}}$ estimates (0.0000 and 0.0024).

The magnitude of genetic differentiation between expected- and late-season recruits based on putatively adaptive loci was higher in $2017\left(F_{\mathrm{ST}}\right.$ range: 0.3411-0.4209) compared to 2018 ( $F_{\mathrm{ST}}$ range: $0.1124-0.2071$; Table 7). Furthermore, greater differentiation was observed between 2017 and 2018 recruits $\left(F_{\mathrm{ST}}\right.$ range: $\left.0.0687-0.3978\right)$ than within the 2018 recruits ( $F_{\mathrm{ST}}$ range: $0.1124-0.2071$; Table 7 ). Interestingly, the 2018 Yaquina Bay late-season recruits were differentiated from the 2017 late-season recruits in both Yaquina Bay $\left(F_{\mathrm{ST}}=0.3352\right)$ and Coos Bay $\left(F_{\mathrm{ST}}=0.2776\right)$.

\subsection{Effective number of breeders}

The estimated $\mathrm{N}_{\mathrm{b}}$ was high within each year and across all 8 collection timepoints, with the exception of the 2017 Coos Bay expected-season recruits (Table 8). Overall, recruits in 2017 had a lower $\mathrm{N}_{\mathrm{b}}$
(13611) than the recruits in 2018 (49855). In 2017, the $\mathrm{N}_{\mathrm{b}}$ estimates were lower for Coos Bay $\left(\mathrm{N}_{\mathrm{b}}=2772\right.$ and 9390) compared to Yaquina Bay ( $\mathrm{N}_{\mathrm{b}}=$ infinite). Although the $\mathrm{N}_{\mathrm{b}}$ estimates for the 2018 late-season recruits from Yaquina Bay and the June (expectedseason) recruits from Coos Bay were high $\left(\mathrm{N}_{\mathrm{b}}=\right.$ 21489 and 12900, respectively), these values were lower than the $\mathrm{N}_{\mathrm{b}}$ calculated at both sites for the April 2018 (expected-season) recruits $\left(\mathrm{N}_{\mathrm{b}}=\right.$ infinite).

\subsection{Relatedness analyses}

Using the dyadic likelihood estimator of Milligan (2003), neither full-siblings nor half-siblings $(r>0.25)$ were observed within the megalopae sampled. Relatedness among megalopae dyads was low and never exceeded $\mathrm{r}=0.1208$; the mean relatedness across all collection timepoints was $0.0172(n=8$, Table 9). However, when comparing overall relatedness between collection timepoints, the relatedness estimate for the 2017 late-season recruits from Coos Bay $(r=0.0198)$

Table 8. Estimates of effective number of Dungeness crab breeders $\left(\mathrm{N}_{\mathrm{b}}\right)$ with range of $95 \%$ confidence interval (CI) for each collection timepoint and year. Estimates based on the single-sample linkage disequilibrium method of Waples \& Do (2008) with a p-critical value of 0.02 for collection timepoints and a p-critical value of 0.01 for years

\begin{tabular}{|c|c|c|c|c|c|c|c|}
\hline Year & Site & Month & Recruitment season & $\mathrm{N}_{\mathrm{b}}$ & $95 \% \mathrm{CI}$ & $\mathrm{N}_{\mathrm{b}}$ & $95 \% \mathrm{CI}$ \\
\hline \multirow[t]{4}{*}{2017} & \multirow[t]{2}{*}{ Coos Bay } & April & Expected & 2772 & $(1710-7252)$ & \multirow[t]{4}{*}{13611} & \multirow[t]{4}{*}{$(7940-47117)$} \\
\hline & & August & Late & 9390 & (2978-Infinite) & & \\
\hline & \multirow[t]{2}{*}{ Yaquina Bay } & April & Expected & Infinite & (6687-Infinite) & & \\
\hline & & August & Late & Infinite & (8606-Infinite) & & \\
\hline \multirow[t]{4}{*}{2018} & \multirow[t]{2}{*}{ Coos Bay } & April & Expected & Infinite & (6516-Infinite) & \multirow[t]{4}{*}{49855} & \multirow[t]{4}{*}{ (13010-Infinite) } \\
\hline & & June & Expected & 12900 & (3141-Infinite) & & \\
\hline & \multirow[t]{2}{*}{ Yaquina Bay } & April & Expected & Infinite & (4693-Infinite) & & \\
\hline & & August & Late & 21489 & (3641-Infinite) & & \\
\hline
\end{tabular}


Table 9. Estimated relatedness (r) of Dungeness crab megalopae within each collection timepoint using the dyadic likelihood estimator of Milligan (2003). The relatedness among megalopae within the 2017 Coos Bay August timepoint ( $\left.{ }^{*}\right)$ was significantly greater than all other timepoints (95\% confidence interval). Relatedness among megalopae within the 2018 Coos Bay April timepoint ( $\mathrm{(}$ ) was significantly less than the 2017 Yaquina Bay April and August timepoints (‡¥) (95\% confidence interval)

\begin{tabular}{|c|c|c|c|c|}
\hline Year & Site & Month & $\begin{array}{c}\text { Recruitment } \\
\text { season }\end{array}$ & $r$ \\
\hline 2017 & $\begin{array}{l}\text { Coos Bay } \\
\text { Yaquina Bay }\end{array}$ & $\begin{array}{c}\text { April } \\
\text { August } \\
\text { April } \\
\text { August }\end{array}$ & $\begin{array}{l}\text { Expected } \\
\text { Late } \\
\text { Expected } \\
\text { Late }\end{array}$ & $\begin{array}{l}0.0168 \\
0.0198^{*} \\
0.0175^{\text {tI }} \\
0.0176^{\text {t๘ }}\end{array}$ \\
\hline 2018 & $\begin{array}{l}\text { Coos Bay } \\
\text { Yaquina Bay }\end{array}$ & $\begin{array}{l}\text { April } \\
\text { June } \\
\text { April } \\
\text { August }\end{array}$ & $\begin{array}{l}\text { Expected } \\
\text { Expected } \\
\text { Expected } \\
\quad \text { Late }\end{array}$ & $\begin{array}{l}0.0159^{\mp} \\
0.0169 \\
0.0162 \\
0.0166\end{array}$ \\
\hline
\end{tabular}

was significantly greater than all other collection timepoints (r range: $0.0159-0.0176$ ) at a $95 \%$ confidence interval. The relatedness estimate for the 2018 Coos Bay April expected-season recruits $(\mathrm{r}=0.0159)$ was significantly lower than the relatedness estimates for the 2017 Yaquina Bay expected- and lateseason recruits $(r=0.0175$ and 0.0176 , respectively).

\section{DISCUSSION}

We found evidence for spatial and temporal genetic homogeneity among Dungeness crab megalopae recruits in the CCE based on variation at neutral loci. However, based on variation at 2 putatively adaptive loci, genetic differentiation between expected-season (April and June) and late-season (August) recruits was detected across sites and years. Contrary to our hypothesis that genetic differentiation would be greater when the positive PDO was weaker, the magnitude of genetic differentiation between the 2 seasonal recruitment groups based on putatively adaptive loci was greater in 2017 than 2018. Furthermore, megalopae recruits within our sampling groups did not exhibit relatedness measures high enough to indicate cohesive larval dispersal.

\subsection{Genetic differentiation between expected- and late-season megalopae recruits}

Low genetic differentiation between expectedand late-season recruits based on variation at neutral loci was detected in this study as well as in 2014 recruits (Lee \& O'Malley 2020). While the $F_{\mathrm{ST}}$ estimate was the same in 2014 and $2017\left(F_{\mathrm{ST}}=0.0011\right)$, the $F_{\mathrm{ST}}$ estimate was significant in 2014 but not in 2017 and 2018. This is attributed to the inclusion of an additional sampling site and 2 years of data, which required correction for multiple testing using FDR. Previous studies on adult Dungeness crab in the CCE used only neutral loci (microsatellites), and low genetic differentiation was observed among adults within the CCE and higher genetic differentiation was observed between adults in the CCE and other ecosystems (GOA and SSE) (Jackson \& O'Malley 2017, O'Malley et al. 2017, Jackson et al. 2017). Therefore, the finding of low genetic differentiation between expected- and late-season recruits at neutral loci across 3 years suggests that both seasonal groups of recruits originate from within the CCE.

However, the GBS method used in this study allowed us to identify putatively adaptive loci and detect genetic differences between the expected- and late-season recruits, thus providing evidence for divergent selection. These genetic differences may be attributed to (1) pre-settlement selection whereby ocean conditions differentially influenced the genetic composition of successful recruits within the 2 seasonal groups or (2) the 2 seasonal groups originated from different breeding populations that experienced divergent selective pressures. Dungeness crab pelagic larvae are exposed to ocean conditions that vary both intra- and inter-annually (Lough 1976), such that selective pressures influence which individuals survive and thus may result in adaptive differences between recruitment groups. However, successful recruits must also survive to reproductive age to influence future generations. In the $\mathrm{CCE}$, a greater number of megalopae recruit to the nearshore than can be supported by the ecosystem; therefore, only a portion of the annual megalopae recruits survive to reproductive age (Galloway et al. 2017). Reduced survival of maladapted migrants would preserve adaptive genetic variation within and between ecosystems, since population connectivity is determined by both larval exchange and the ability of migrants to survive and reproduce at recruitment locations (Palumbi 2003, Hedgecock et al. 2007, Pineda et al. 2007).

\subsection{Examination of putatively adaptive loci}

The strong genetic differentiation based on variation at putatively adaptive loci was similar to findings from the 2014 study (Lee \& O'Malley 2020); however, 
the 2 putatively adaptive loci identified in the 2014 study were different from the 2 loci identified among the 2017 and 2018 megalopae recruits. While these loci might be located in the same region of the genome, we cannot confirm this without a reference genome. The difference in putatively adaptive loci between the studies may be due to the use of a reduced-representation sequencing approach (i.e. GBS), as well as 'stacks' de novo alignment (Catchen et al. 2011, Catchen et al. 2013). While this is a costeffective method of loci discovery in species without a reference genome, it is not specifically designed to identify the same loci across different experiments (Andrews et al. 2016).

Outlier loci identified in genome-wide scans do not necessarily represent adaptive loci (Shafer et al. 2015), and the lack of reference genomes for crustaceans makes it difficult to annotate outlier loci (Rotllant et al. 2018). However, 1 putatively adaptive locus (CLocus_24; Table S5) matched a SOX-1-like transcription factor in Pacific white shrimp (Zhang et al. 2019). In humans, SOX-1 is a transcription factor involved in regulating embryonic development (NCBI Gene ID: 6656). Interestingly, the development timing differs between expected- and lateseason recruits (Rasmuson 2013, Shanks 2013). This could support the hypotheses that (1) the late-season recruits originate from a northern ecosystem, given that hatch timing differs between northern and southern ecosystems (Rasmuson 2013) or (2) the lateseason recruits represent megalopae with an extended PLD, and subsequently, a longer development time than expected-season recruits (Wild \& Tasto 1983).

In Dungeness crab megalopae, sex cannot be determined morphologically. Therefore, the sex ratios in our samples were unknown, and it is possible that the putatively adaptive loci may represent sex-linked variation (Benestan et al. 2017). However, by using large sample sizes, randomly sampling megalopae at 2 sites and across 2 years, and then combining data in an inter-annual analysis, we reduced the potential of uneven sex ratios influencing genetic differentiation measurements.

\subsection{Inter-annual differences among megalopae recruits}

Although intra-annual genetic differentiation based on putatively adaptive loci was observed within Dungeness crab recruits in both 2017 and 2018, the magnitude of genetic differentiation varied inter- annually. The results did not support our hypothesis that stronger intra-annual genetic differentiation would be detected in 2018 compared to 2017 due to ocean conditions. In contrast, genetic differentiation between the 2017 recruits was stronger $\left(F_{\mathrm{ST}}\right.$ range $=$ 0.3411-0.4209) than the genetic differentiation between the 2018 recruits $\left(F_{\mathrm{ST}}=0.1124-0.2971\right)$. This finding deviates from predictions based on ocean conditions which indicated greater potential for southward larval transport from the GOA or SSE to the CCE in 2018 than in 2017 (Shanks 2013).

Jackson et al. (2017) detected inter-annual variation in population genetic structure of adult Dungeness crabs sampled within the CCE based on neutral loci, and these findings were attributed to differences in ocean conditions (i.e. PDO, upwelling, and spring transition) during the PLD of each year-class. Similarly, the variation in magnitude of intra-annual genetic differentiation across years $(2014,2017,2018)$ may be attributed to differences in ocean conditions (Lee \& O'Malley 2020). When comparing ocean conditions, 2014 had the strongest positive PDO, weakest upwelling, and latest spring transition, followed by 2017 and then 2018 (Table 1). These 3 ocean parameters have been correlated with lower overall abundances of megalopae recruits in Coos Bay (Shanks \& Roegner 2007, Shanks et al. 2010, Shanks 2013). True to the correlations, the total abundances of megalopae recruits in 2014 and 2017 were below average and the total abundance of megalopae recruits in 2018 was well above average. Based on these ocean conditions, we hypothesized that years with stronger positive PDOs would have the weakest intra-annual genetic differentiation due to a weaker southern-flowing California Current in the CCE, which would reduce southward larval transport of Dungeness crabs. However, the year with the strongest positive PDO (2014) had the highest intraannual genetic differentiation, and the year with the weakest positive PDO (2018) had the lowest genetic differentiation based on putatively adaptive loci. Since only years with positive PDOs were examined, future studies should examine negative PDO years to test if this pattern is consistent across different regimes. Furthermore, other ocean conditions besides PDO likely influence larval dispersal, such as El Niño/Southern Oscillation (ENSO) events, which can strengthen the northward California Undercurrent and northward Davidson Current within the CCE (Lynn \& Bograd 2002).

Few late-season Dungeness crab megalopae recruits were observed in 2018. In Coos Bay, only 1 late-season megalopa recruit was sampled while a 
few hundred were sampled in Yaquina Bay. Prior to 2018, the lowest number of late-season megalopae recruits recorded in Coos Bay during sampling years spanning both expected-season and late-season time periods (16 yr dataset) was just over 3000 megalopae in 2016 (Shanks \& Roegner 2007, Shanks et al. 2010, Shanks 2013, 2019, Rasmuson \& Shanks 2020, A. Shanks unpubl. data). Our results suggest that local ocean conditions may have differed between the 2 sites (Hickey \& Banas 2003), or that regional ocean conditions (e.g. PDO) limited the southward transport distance of pelagic larvae via the California Current (Coos Bay is $144 \mathrm{~km}$ south of Yaquina Bay). Interestingly, the 2018 late-season recruits in Yaquina Bay were genetically differentiated from the lateseason recruits in 2017 (both Coos and Yaquina Bays), a finding that may be attributed to differences in larval dispersal distances between years.

The inclusion of a second expected-season timepoint (June) in Coos Bay in 2018 provided an opportunity to further test the hypothesis that intra-annual genetic differentiation exists specifically between the expected- and late-season groups based on life history timing. Based on our hypothesis, any megalopae recruits sampled from April through July (expected-season) should be genetically similar to each other yet genetically different from late-season recruits (August through September). In 2018, the expected-season April (Yaquina and Coos Bays) and June (Coos Bay) megalopae recruits were not genetically differentiated based on variation at putatively adaptive loci, but they were all genetically differentiated from the late-season August 2018 recruits in Yaquina Bay. The genetic similarity between April and June recruits provides evidence against the alternative hypothesis that any 2 collections of megalopae recruits sampled on different days throughout the season are genetically differentiated. Furthermore, despite differences in megalopae recruitment abundances between Coos Bay and Yaquina Bay in 2018, seasonal genetic differentiation was still observed across both sites.

\subsection{Relatedness of megalopae recruits}

Offspring from a female Dungeness crab are released together but influenced by ocean conditions during the long PLD prior to recruitment (Wild \& Tasto 1983, Rasmuson 2013). Therefore, larval ecology suggests that cohesive larval dispersal of related individuals (kin) is less likely because of larval mixing within the water column (Victor 1984, Selkoe et al. 2008). However, kinship aggregation has been documented in several other marine species with long PLDs using genetic relatedness measures (Iacchei et al. 2013, Adrian et al. 2017, Riquet et al. 2017), and higher than expected relatedness has been observed among adult Dungeness crab at several locations within the CCE (Jackson et al. 2017). We hypothesized that related megalopae would be observed within collection timepoints, indicating that Dungeness crab pelagic larvae exhibit cohesive larval dispersal. However, the relatedness analysis of the 2017 and 2018 megalopae indicated that Dungeness crab megalopae recruits did not exhibit cohesive larval dispersal. Additionally, $\mathrm{N}_{\mathrm{b}}$ was not notably reduced within collection timepoints or years.

\subsection{Changing ocean conditions and implications for the fishery}

With our findings of neutral genetic homogeneity and evidence for divergent selection, we cannot reject our hypothesis that late-season recruits represent larvae from a northern ecosystem (SSE or GOA) (Shanks 2013). However, further evidence is needed to confirm the origin of the late-season recruits, such as genetic assignment of CCE megalopae recruits to adult samples from northern ecosystems or development of biophysical models. Moreover, our results suggest that the timing of Dungeness crab life history events in the CCE should be studied more thoroughly to better understand temporal differences observed among recruits. The late-season recruits may represent a group of megalopae with an extended PLD, a longer developmental timing, or a later hatching time (Wild \& Tasto 1983). More importantly, phenology of marine species life histories are shifting with changing ocean conditions (Asch 2015). Documenting life history and developmental changes in Dungeness crab remains important to the management of the fishery. Currently, the CCE Dungeness crab commercial fishery is managed under the 3-S system whereby only males of a specific size are harvested during a defined season (Rasmuson 2013). This management strategy assumes that males have the opportunity to reproduce at least once before being harvested. Moreover, it is estimated that in the last 2 decades, an average of $79 \%$ of legal sized males were harvested each year in the CCE (Richerson et al. 2020). Under this management strategy, it is important to maintain a current and complete understanding of the timing of maturation, mating, and development of this species. 
The Dungeness crab megalopae recruitment abundance and timing patterns in 2018 were anomalous. Considering data collected over the past 2 decades, 2018 had the highest number of recruits ever observed and was the first time a negligible number of late-season recruits was observed in Coos Bay (Shanks \& Roegner 2007, Shanks et al. 2010, Shanks 2013, 2019, A. Shanks unpubl. data). Lower abundances of late-season recruits are often observed in years with stronger positive PDOs, which is hypothesized to be attributed to weaker southward transport by the California Current (Shanks 2013). However, 2017 had a stronger positive PDO than 2018, but more late-season recruits. Moreover, greater intraannual genetic differentiation was observed in 2017 than 2018, contrary to the observed ocean conditions. Considering the timing of Dungeness crab life history, the megalopae recruiting within the CCE during the marine heatwave and ENSO events of 2015-2016 (i.e. 'the Blob'; Peterson et al. 2017) composed a majority of the breeding population for the 2018 megalopae recruits. This may have impacted the recruits (either through physical oceanography, ecological conditions, or physiological tolerance of the species) and thus resulted in atypical patterns. With changing ocean conditions, it is becoming important to understand genetic variation, between and within ecosystems, due to selective pressures such as increasing water temperatures and marine heat waves.

The complex relationship between larval dispersal and ocean conditions during the PLD is still poorly understood. Future studies combining genetic analyses with physical transport models (Segura-García et al. 2019) or oceanographic models (Norton et al. 2020) may be informative toward understanding why both intra- and inter-annual differences in Dungeness crab megalopae were observed based on variation at putatively adaptive loci. Here, we examined a vulnerable early life history stage of a marine species in the context of larval dispersal and 3 well-studied ocean parameters (i.e. PDO, upwelling, and spring transition) (Shanks \& Roegner 2007, Shanks et al. 2010, Shanks 2013); however, other ocean parameters impact Dungeness crab larvae (e.g. temperature, salinity, dissolved oxygen, nutrients, nitrate, chlorophyll) (Miller et al. 2016, Bednaršek et al. 2020, Norton et al. 2020). Future studies implementing interdisciplinary approaches to examine an array of physical, biological, chemical, and ecological variables would be informative (Bashevkin et al. 2020), since Dungeness crab population connectivity is shaped by both larval dispersal and survival of re- cruits to reproductive age. With changing ocean conditions, it is likely that atypical patterns in larval dispersal and larval recruitment will be observed more often. Variations in larval recruits due to changing ocean conditions may eventually impact fishery harvests, fishery-reliant communities, and the Dungeness crab industry. Therefore, studying this vulnerable, early life history stage is vital to understanding population connectivity within this socially and economically valuable marine species.

Data accessibility. Sequence data are archived in NCBI SRA, BioProject accession: PRJNA587891.

Acknowledgements. We thank Alan Shanks and the members of the Shanks Lab at the Oregon Institute of Marine Biology, University of Oregon, for providing the Coos Bay megalopae samples and light trap abundance data for this study. We also thank Oregon State University's Center of Genome Research and Biocomputing for preparing and sequencing our megalopae samples. Special thanks to the members of the State Fisheries Genomics Lab at Hatfield Marine Science Center for providing valuable guidance throughout this project. This study was funded by NSF-NRT award 1545188 ('Risk and uncertainty quantification and communication in marine science and policy'), the Oregon Sea Grant Robert E. Malouf Marine Studies Scholarship (grant NA14OAR4170064 and project E/INT-157), the Hatfield Marine Science Center Mamie Markham Research Award, the Hatfield Marine Science Center Bill Wick Fisheries award, and the Oregon Department of Fish and Wildlife Marine Reserve Graduate Student Scholarship. The statements, findings, conclusions, and recommendations are those of the authors and do not necessarily reflect the views of these funders. All applicable international, national, and institutional guidelines for the care and use of animals were followed.

\section{LITERATURE CITED}

Adrian AJ, Lack CE, Kamel SJ (2017) Kin aggregations occur in eastern oyster Crassostrea virginica reefs despite limited regional genetic differentiation. Mar Ecol Prog Ser 584:79-90

Altschul SF, Gish W, Miller W, Myers EW, Lipman DJ (1990) Basic local alignment search tool. J Mol Biol 215:403-410

Anderson EC (2018) Whoa: evaluation of genotyping error in genotype by sequencing data. https://github.com/ eriqande/whoa (accessed 1 Dec 2018)

Andrews KR, Good JM, Miller MR, Luikart G, Hohenlohe PA (2016) Harnessing the power of RADseq for ecological and evolutionary genomics. Nat Rev Genet 17:81-92

Angeloni F, Wagemaker N, Vergeer P, Ouborg J (2012) Genomic toolboxes for conservation biologists. Evol Appl 5:130-143

Asch RG (2015) Climate change and decadal shifts in the phenology of larval fishes in the California Current ecosystem. Proc Natl Acad Sci USA 112:E4065-E4074

Bashevkin SM, Dibble CD, Dunn RP, Hollarsmith JA, Ng G, Satterthwaite EV, Morgan SG (2020) Larval dispersal in a changing ocean with an emphasis on upwelling regions. Ecosphere 11:e03015 
Bednaršek N, Feely RA, Beck MW, Alin SR and others (2020) Exoskeleton dissolution with mechanoreceptor damage in larval Dungeness crab related to severity of present-day ocean acidification vertical gradients. Sci Total Environ 716:136610

Benestan L, Moore JS, Sutherland BJG, Le Luyer J and others (2017) Sex matters in massive parallel sequencing: evidence for biases in genetic parameter estimation and investigation of sex determination systems. Mol Ecol 26: 6767-6783

Bograd SJ, Schroeder I, Sarkar N, Qiu X, Sydeman WJ, Schwing FB (2009) Phenology of coastal upwelling in the California Current. Geophys Res Lett 36:L01602

* Catchen JM, Amores A, Hohenlohe P, Cresko W, Postlethwait JH (2011) Stacks: building and genotyping loci de novo from short-read sequences. G3 (Bethesda) 1: $171-182$

* Catchen J, Hohenlohe PA, Bassham S, Amores A, Cresko WA (2013) Stacks: an analysis tool set for population genomics. Mol Ecol 22:3124-3140

Checkley DM, Barth JA (2009) Patterns and processes in the California Current System. Prog Oceanogr 83:49-64

* Cowen RK, Sponaugle S (2009) Larval dispersal and marine population connectivity. Annu Rev Mar Sci 1:443-466

Cowen RK, Gawarkiewicz G, Pineda J, Thorrold SR, Werner FE (2007) Population connectivity in marine systems an overview. Oceanography 20:14-21

Danecek P, Auton A, Abecasis G, Albers CA and others (2011) The variant call format and VCFtools. Bioinformatics 27:2156-2158

Diamond N, Hankin DG (1985) Movements of adult female Dungeness crabs (Cancer magister) in northern California based on tag recoveries. Can J Fish Aquat Sci 42: 919-926

* Do C, Waples RS, Peel D, Macbeth GM, Tillett BJ, Ovenden JR (2014) NeEstimator v2: re-implementation of software for the estimation of contemporary effective population size $\left(N_{e}\right)$ from genetic data. Mol Ecol Resour 14:209-214

Elshire RJ, Glaubitz JC, Sun Q, Poland JA, Kawamoto K, Buckler ES, Mitchell SE (2011) A robust, simple genotyping-by-sequencing (GBS) approach for high diversity species. PLOS ONE 6:e19379

Flanagan SP, Jones AG (2017) Constraints on the $F_{\mathrm{ST}^{-}}$ heterozygosity outlier approach. J Hered 108:561-573

Foll M, Gaggiotti O (2008) A genome-scan method to identify selected loci appropriate for both dominant and codominant markers: a Bayesian perspective. Genetics 180:977-993

Gagnaire PA, Broquet T, Aurelle D, Viard F and others (2015) Using neutral, selected, and hitchhiker loci to assess connectivity of marine populations in the genomic era. Evol Appl 8:769-786

Galloway AW, Shanks AL, Groth S, Marion SR, Thurber AR (2017) Massive crab recruitment events to the shallow subtidal zone. Ecology 98:1468-1470

Goudet J (2005) Hierfstat, a package for R to compute and test hierarchical F-statistics. Mol Ecol Notes 5:184-186

Grosberg R, Cunningham CW (2001) Genetic structure in the sea: from populations to communities. In: Bertness MD, Gains SD, Hay ME (eds) Marine community ecology. Sinauer, Sunderland, MA, p 61-84

Hedgecock D, Barber PH, Edmands S (2007) Genetic approaches to measuring connectivity. Oceanography 20: $70-79$
Hellberg ME (2009) Gene flow and isolation among populations of marine animals. Annu Rev Ecol Evol Syst 40: 291-310

Hellberg ME, Burton RS, Neigel JE, Palumbi SR (2002) Genetic assessment of connectivity among marine populations. Bull Mar Sci 70:273-290

Hickey BM, Banas NS (2003) Oceanography of the US Pacific Northwest coastal ocean and estuaries with application to coastal ecology. Estuaries 26:1010-1031

Hildenbrand K, Gladics A, Eder B (2011) Crab tagging study: adult male Dungeness crab (Metacarcinus magister) movements near Reedsport, Oregon from a fisheries collaborative mark-recapture study. Oregon Wave Energy Trust, Portland, OR

Iacchei M, Ben-Horin T, Selkoe KA, Bird CE, GarcíaRodríguez FJ, Toonen RJ (2013) Combined analyses of kinship and $F_{\mathrm{ST}}$ suggest potential drivers of chaotic genetic patchiness in high gene-flow populations. Mol Ecol 22:3476-3494

Jackson TM, O'Malley KG (2017) Comparing genetic connectivity among Dungeness crab (Cancer magister) inhabiting Puget Sound and coastal Washington. Mar Biol 164:123

Jackson TM, Roegner GC, O'Malley KG (2017) Evidence for interannual variation in genetic structure of Dungeness crab (Cancer magister) along the California Current System. Mol Ecol 27:352-368

JISAO (Joint Institute for the Study of the Atmosphere and Ocean) (2019) PDO Index. http://research.jisao. washington.edu/pdo/PDO.latest.txt (accessed 1 Mar 2019)

Jombart T, Devillard S, Balloux F (2010) Discriminant analysis of principal components: a new method for the analysis of genetically structured populations. BMC Genet 11:94

Keister JE, Di Lorenzo E, Morgan CA, Combes V, Peterson WT (2011) Zooplankton species composition is linked to ocean transport in the Northern California Current. Glob Change Biol 17:2498-2511

Kelly RP, Palumbi SR (2010) Genetic structure among 50 species of the northeastern Pacific rocky intertidal community. PLOS ONE 5:e8594

Kool JT, Moilanen A, Treml EA (2013) Population connectivity: recent advances and new perspectives. Landsc Ecol 28:165-185

พ Lee EMJ, O'Malley KG (2020) Big fishery, big data, and little crabs: using genomic methods to examine the seasonal recruitment patterns of early life stage Dungeness crab (Cancer magister) in the California Current Ecosystem. Front Mar Sci 6:836

Li YH, Wang HP (2017) Advances of genotyping-by-sequencing in fisheries and aquaculture. Rev Fish Biol Fish 27: 535-559

Lough RG (1976) Larval dynamics of Dungeness crab, Cancer magister, off the central Oregon coast, 1970-11. Fish Bull 74:353-376

Lowe WH, Allendorf FW (2010) What can genetics tell us about population connectivity? Mol Ecol 19:3038-3051

* Lynn RJ, Bograd SJ (2002) Dynamic evolution of the 19971999 El Niño-La Niña cycle in the southern California Current system. Prog Oceanogr 54:59-75

Marko PB, Hart MW (2018) Genetic analysis of larval dispersal, gene flow, and connectivity. In: Carrier TJ, Reitzel AM, Heyland A (eds) Evolutionary ecology of marine invertebrate larvae. Oxford University Press, Oxford, p 165-166 * Miller JJ, Maher M, Bohaboy E, Friedman CS, McElhany P 
(2016) Exposure to low pH reduces survival and delays development in early life stages of Dungeness crab (Cancer magister). Mar Biol 163:118

Milligan BG (2003) Maximum-likelihood estimation of relatedness. Genetics 163:1153-1167

Narum SR, Hess JE (2011) Comparison of $F_{\text {ST }}$ outlier tests for SNP loci under selection. Mol Ecol Resour 11:184-194

Narum SR, Buerkle CA, Davey JW, Miller MR, Hohenlohe PA (2013) Genotyping-by-sequencing in ecological and conservation genomics. Mol Ecol 22:2841-2847

Nielsen EE, Hemmer-Hansen JA, Larsen PF, Bekkevold D (2009) Population genomics of marine fishes: identifying adaptive variation in space and time. Mol Ecol 18: 3128-3150

Norton EL, Siedlecki S, Kaplan IC, Hermann AJ and others (2020) The importance of environmental exposure history in forecasting Dungeness crab megalopae occurrence using J-SCOPE, a high-resolution model for the US Pacific Northwest. Front Mar Sci 7:102

O'Malley KG, Corbett K, Beacham TD, Jacobson DP, Jackson TM, Roegner GC (2017) Genetic connectivity of the Dungeness crab (Cancer magister) across oceanographic regimes. J Shellfish Res 36:453-465

Pacific Fisheries Environmental Laboratory (2019) Upwelling Indices. www.pfeg.noaa.gov/products/PFEL/modeled/ indices/upwelling/upwelling.html (accessed 1 Mar 2019)

* Palumbi SR (2003) Population genetics, demographic connectivity, and the design of marine reserves. Ecol Appl 13:146-158

Paradis E (2010) Pegas: an R package for population genetics with an integrated-modular approach. Bioinformatics 26:419-420

* Pembleton LW, Cogan NO, Forster JW (2013) Stampp: an R package for calculation of genetic differentiation and structure of mixed-ploidy level populations. Mol Ecol Resour 13:946-952

Peterson WT, Fisher JL, Strub PT, Du X, Risien C, Peterson J, Shaw CT (2017) The pelagic ecosystem in the Northern California Current off Oregon during the 2014-2016 warm anomalies within the context of the past 20 years. J Geophys Res C Oceans 122:7267-7290

* Pineda J, Hare JA, Sponaugle S (2007) Larval transport and dispersal in the coastal ocean and consequences for population connectivity. Oceanography 20:22-39

R Core Team (2019) R: a language and environment for statistical computing. R Foundation for Statistical Computing, Vienna

Rasmuson LK (2013) The biology, ecology and fishery of the Dungeness crab, Cancer magister. Adv Mar Biol 65: 95-148

Rasmuson LK, Shanks AL (2014) In situ observations of Dungeness crab megalopae used to estimate transport distances by internal waves. Mar Ecol Prog Ser 511:143-152

Rasmuson LK, Shanks AL (2020) Revisiting cross-shelf transport of Dungeness crab (Metacarcinus magister) megalopae by the internal tide using 16 years of daily abundance data. J Exp Mar Biol Ecol 527:151334

Richerson K, Punt AE, Holland DS (2020) Nearly a half century of high but sustainable exploitation in the Dungeness crab (Cancer magister) fishery. Fish Res 226:105528

Riquet F, Comtet T, Broquet T, Viard F (2017) Unexpected collective larval dispersal but little support for sweepstakes reproductive success in the highly dispersive brooding mollusc Crepidula fornicata. Mol Ecol 26: 5467-5483
Rochette NC, Catchen JM (2017) Deriving genotypes from RAD-seq short-read data using Stacks. Nat Protoc 12: 2640

Rotllant G, Palero F, Mather PB, Bracken-Grissom HD, Santos MB (2018) Preface: Recent advances in crustacean genomics. Hydrobiologia 825:1-4

* Segura-García I, Garavelli L, Tringali M, Matthews T, Chérubin LM, Hunt J, Box SJ (2019) Reconstruction of larval origins based on genetic relatedness and biophysical modeling. Sci Rep 9:7100

Selkoe KA, Toonen RJ (2011) Marine connectivity: a new look at pelagic larval duration and genetic metrics of dispersal. Mar Ecol Prog Ser 436:291-305

Selkoe KA, Henzler CM, Gaines SD (2008) Seascape genetics and the spatial ecology of marine populations. Fish Fish 9:363-377

* Shafer ABA, Wolf JBW, Alves PC, Bergström L and others (2015) Genomics and the challenging translation into conservation practice. Trends Ecol Evol 30:78-87

Shanks AL (2013) Atmospheric forcing drives recruitment variation in the Dungeness crab (Cancer magister), revisited. Fish Oceanogr 22:263-272

Shanks AL (2019) Report on the recruitment of Dungeness crab megalopae during the 2018 recruitment season. Report to the Oregon Dungeness Crab Commission, Coos Bay, OR

* Shanks AL, Roegner GC (2007) Recruitment limitation in Dungeness crab populations is driven by variation in atmospheric forcing. Ecology 88:1726-1737

Shanks AL, Roegner GC, Miller J (2010) Using megalopae abundance to predict future commercial catches of Dungeness crabs (Cancer magister) in Oregon. Calif Coop Ocean Fish Invest Rep 51:106-118

* Victor BC (1984) Coral reef fish larvae: patch size estimation and mixing in the plankton 1. Limnol Oceanogr 29: 1116-1119

Wang J (2011) Coancestry: a program for simulating, estimating and analysing relatedness and inbreeding coefficients. Mol Ecol Resour 11:141-145

*Waples RS, Do C (2008) LDNE: a program for estimating effective population size from data on linkage disequilibrium. Mol Ecol Resour 8:753-756

Waples RS, Do C (2010) Linkage disequilibrium estimates of contemporary $N_{e}$ using highly variable genetic markers: a largely untapped resource for applied conservation and evolution. Evol Appl 3:244-262

Weir BS, Cockerham CC (1984) Estimating F-statistics for the analysis of population structure. Evolution 38:13581370

*Whitlock MC, Lotterhos KE (2015) Reliable detection of loci responsible for local adaptation: inference of a null model through trimming the distribution of $F_{\mathrm{ST}}$. Am Nat 186(Suppl 1):S24-S36

*Wigginton JE, Cutler DJ, Abecasis GR (2005) A note on exact tests of Hardy-Weinberg equilibrium. Am J Hum Genet 76:887-893

Wild PW, Tasto RN (1983) Life history, environment, and mariculture studies of the Dungeness crab, Cancer magister, with emphasis on the central California fishery resource. No. 172. Department of Fish and Game, Sacramento, CA

* Zhang X, Yuan J, Zhang X, Liu C, Li F, Xiang J (2019) Genome-wide identification and expression profiles of myosin genes in the Pacific white shrimp, Litopenaeus vannamei. Front Physiol 10:610 